\title{
The ENOD12 Gene Product Is Involved in the Infection Process during the Pea-Rhizobium Interaction
}

\author{
Ben Scheres," Clemens Van De Wiel," + \\ Andrei Zalensky," Beatrix Horvath," \\ Herman Spaink, $¥$ Herman Van Eck, \\ Fried Zwartkruis," Anne-Marie Wolters," \\ Ton Gloudemans," Ab Van Kammen," \\ and Ton Bisseling* \\ * Department of Molecular Biology \\ Agricultural University \\ 6703 HA Wageningen \\ The Netherlands \\ tDepartment of Plant Cytology and Morphology \\ Agricultural University \\ 6703 BD Wageningen \\ The Netherlands \\ ‡Department of Plant Molecular Biology \\ University of Leiden \\ The Netherlands
}

\section{Summary}

The pea cDNA clone pPsENOD12 represents a gene involved in the infection process during Pisum sativum L.-Rhizobium leguminosarum bv. viciae symbiosis. The ENOD12 protein is composed of pentapeptides containing two hydroxyprolines. The expression of the ENOD12 gene is induced in cells through which the infection thread is migrating, but also in cells that do not yet contain an infection thread. Soluble compounds from Rhizobium are involved in eliciting ENOD12 gene expression. Rhizobium common and host-specific nodulation genes are essential for the production of these compounds. Two ENOD12 genes are expressed in nodules and in stem tissue of uninoculated plants. The gene represented by the cloned ENOD12 mRNA is also expressed in flowers, but a different transcription start may be used.

\section{Introduction}

The symbiosis between Rhizobium bacteria and legumes results in the formation of highly organized structures, namely, infection threads and root nodules. These nodules, in which nitrogen fixation takes place, consist of different tissues organized in a specific way (Newcomb, 1980).

The infection process begins with the deformation and curling of root hairs (Bauer, 1981). Curling is thought to achieve enclosure of attached bacteria, permitting them to locally modify and hydrolyze the cell wall of the root hairs (Callaham and Torrey, 1981; Turgeon and Bauer, 1985). At this site, cell wall material is deposited by the plant, and it forms tubular structures: the infection threads. Infection threads, containing dividing bacteria, grow into the root cortex. In pea roots the infection thread proceeds toward the inner cortical cell layers, where the following events occur. Prior to penetration of the infection thread into root cortex cells, the cells change remarkably: as microtubules rearrange, an additional cell wall layer is deposited, and a cytoplasmic bridge is formed by which the infection thread will migrate. The infection thread passes through the prepared cells by a cell wall degradation and deposition mechanism, just as in root hairs (Bakhuizen et al., 1988). Concomitantly with infection thread formation, rhizobia induce the formation of a premeristem, the nodule primordium, in the inner cortical cell layers. Infection threads grow into the nodule primordium, where bacteria are released from the infection thread tips (Libbenga and Bogers, 1974). Simultaneously, the meristem is formed at the apical site of the nodule primordium. Meristem cells are smaller in size and have smaller vacuoles than primordium cells. The direction of infection thread growth is then reversed: it now follows the apical meristem growing out of the root by adding cells that differentiate into the various nodule tissues. In this way there is a continuous infection process in the so-called invasion zone, immediately adjacent to the meristem. Upon release of bacteria in the plant cells, the bacteria are encapsulated by a membrane of plant origin and differentiate into $\mathrm{N}_{2}$-fixing bacteroids (Newcomb, 1976).

It has been shown that both bacterial and plant genes are involved in nodule formation. For example, the bacterial common and host-specific nodulation (nod) genes are involved in root hair deformation, infection thread formation, and induction of cortical cell division (for review see Long, 1989). They are also essential for the induction of expression of nodule-specific plant genes, the nodulin genes (Van Kammen, 1984; Govers et al., 1986). Nodulin genes can, according to the timing of their expression during nodule development, be divided into early and late nodulin genes (Govers et al., 1987). Early nodulins are involved in root hair deformation, infection, or nodule morphogenesis. The best studied early nodulin is ENOD2. It is a hydroxyproline-rich protein that is most likely a cell wall component (Franssen et al., 1987) and that is formed in nodule parenchyma ("inner cortex") cells (Van De Wiel et al., 1990). Late nodulins are detectable after the nodule has developed and bacterial release has taken place. Therefore, they are neither involved in infection nor in nodule morphogenesis. Well characterized late nodulins are the leghemoglobins (Brisson and Verma, 1982) and a nodule-specific uricase (Bergmann et al., 1983), involved in oxygen transport and nitrogen metabolism, respectively. Several late nodulins are located in the peribacteroid membrane, but their function is yet unknown (Fortin et al., 1985, 1987; Jacobs et al., 1987; Sandal et al., 1987).

The early nodulins characterized so far, GmENOD2, GmENOD13, and GmENOD55, are related to nodule morphogenesis and not to the infection process (Franssen et al., 1987, 1988). Our aim was to isolate a cDNA clone encoding a nodulin involved in the infection process and to investigate the role of plant genes in this process and the regulation of their expression by Rhizobium. The infection process occurs abundantly in the invasion zone of young 


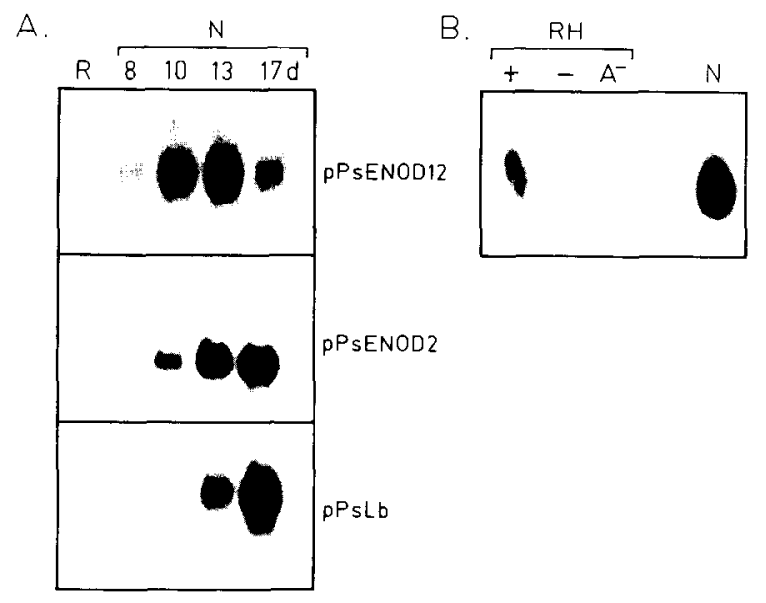

Figure 1. RNA Transfer Blot Analysis of RNA from Roots, Nodules, and Root Hairs

(A) RNA transfer blots contain $10 \mu \mathrm{g}$ of total RNA from uninoculated roots of 8 day old plants $(R)$, and nodules $(N), 8,10,13$, and 17 days after sowing and inoculation. Blots were probed with PPSENOD12, PPSENOD2 and PPsLb inserts, respectively.

(B) RNA transfer blot contains $20 \mu \mathrm{g}$ of total RNA from root hairs (RH), and nodules 13 days after inoculation $(\mathrm{N})$. Plants were inoculated 3 days after sowing, and root hairs were harvested $48 \mathrm{hr}$ after inoculation (plus sign); after $48 \mathrm{hr}$ without inoculation (minus sign); and $48 \mathrm{hr}$ after inoculation with $R$. leguminosarum bv. viciae A10 (nodA:Th5) (A). The blot was probed with PPSENOD12 insert.

pea nodules, where many cells derived from the meristem are penetrated by an infection thread. Therefore, we decided to isolate early nodulin cDNA clones from a pea nodule cDNA library. The infection process occurs in root hairs as well as in nodules, so we selected putative infection-related clones by testing whether the corresponding genes are expressed both in root hairs of inoculated plants and in nodules. With this approach we obtained a cDNA clone representing an early nodulin gene involved in the infection process. We report on the characterization of the ENOD12 cDNA clone, the regulation of expression of the corresponding gene by Rhizobium, and its possible function in the infection process. Furthermore, we discuss the evolutionary origin of this nodulin gene, since transcripts homologous to this cDNA clone were detected in stem and flower tissues.

\section{Results}

\section{Isolation of an Infection-Related Early}

\section{Nodulin cDNA Clone}

A pea nodule cDNA library was differentially screened with cDNA probes made of RNA from nodules from 10 day old plants and from uninfected roots from 8 day old plants. One of the isolated nodulin clones, PPSENOD12, appeared to encode an early nodulin potentially involved in the infection process. RNA transfer blot analysis revealed that ENOD12 mRNA has a transient pattern of appearance during nodule development (Figure 1A). It is already detectable in root segments of 8 day old infected pea plants, which do not possess macroscopically visible nod- ules. The mRNA reaches its maximum concentration from day 10 to 13 and decreases in concentration thereafter. In contrast to ENOD12 mRNA, the transcript of the pea early nodulin ENOD2 is first detectable on similar blots at day 10 and reaches a maximum concentration between day 13 and 17 , and the concentration remains constant thereafter. The mRNA of the late nodulin leghemoglobin is first detectable at day 13 and increases in concentration during the following days (Figure 1A).

Next, we determined whether the ENOD12 gene was expressed in root hairs from inoculated plants, using RNA transfer blot analysis. This study revealed that the ENOD12 transcript is present in root hairs $24 \mathrm{hr}$ after inoculation, but not in root hairs from uninoculated peas (Figure 1B, $\mathrm{RH}^{\prime+}+$ " and "-" lanes). The presence of the ENOD12 transcript in root hairs of plants shortly after inoculation indicates that ENOD12 gene expression may correlate with the occurrence of the infection process.

\section{Localization of ENOD12 mRNA in Root Cortex and Nodule Cells}

The correlation between ENOD12 gene expression and the occurrence of infection threads was further examined by in situ hybridization. Roots of pea plants inoculated with bacteria 3 days after sowing were harvested 2 and 3 days after inoculation. They were embedded in paraffin, and serial sections containing nodule primordia and infection threads were selected. These sections were hybridized to ${ }^{35}$ S-labeled antisense ENOD12 RNA.

Two days after inoculation ENOD12 transcript appeared to be located in cortex cells containing the infection thread (Figures 2A and 2B, small arrowhead and arrow). In root hairs where infection threads are present, ENOD12 mRNA is also detected (Figures $2 \mathrm{~A}$ and $2 \mathrm{~B}$, arrow). By analysis of serial sections, we determined the location of the tip of the infection thread (Figure 2A, small arrowhead), and the ENOD12 transcript appeared not to be confined to cells containing an infection thread. A track of cortical cells in front of the thread, toward the central cylinder, also contained ENOD12 mRNA (Figure 2B). From cytological studies it is known that these cells undergo several morphological changes and become "prepared" for infection thread passage (Bakhuizen et al., 1988). Moreover, ENOD12 transcript is also present in cells in the root inner cortex (Figures 2A and 2B, large arrowhead), which form the nodule primordium (Libbenga and Bogers, 1974).

Three days after inoculation a center of mitotic activity, the nodule primordium, is clearly visible in the inner cortical cell layers, containing dividing cells that possess enlarged nuclei and a higher content of cytoplasm than the root cortex cells (Figure 2C). The infection thread (arrow) has not yet reached the primordium. At this stage ENOD12 mRNA can be detected in the cortex cells containing the infection thread, in the cells preparing for infection thread passage, and also in the cells that form the new center of mitotic activity, the nodule primordium (Figures 2C and 2D).

We also localized ENOD12 transcript in pea nodules at later stages of development. Sections from pea nodules of 7,10 , and 20 day old plants were hybridized with ${ }^{35} \mathrm{~S}$-la- 

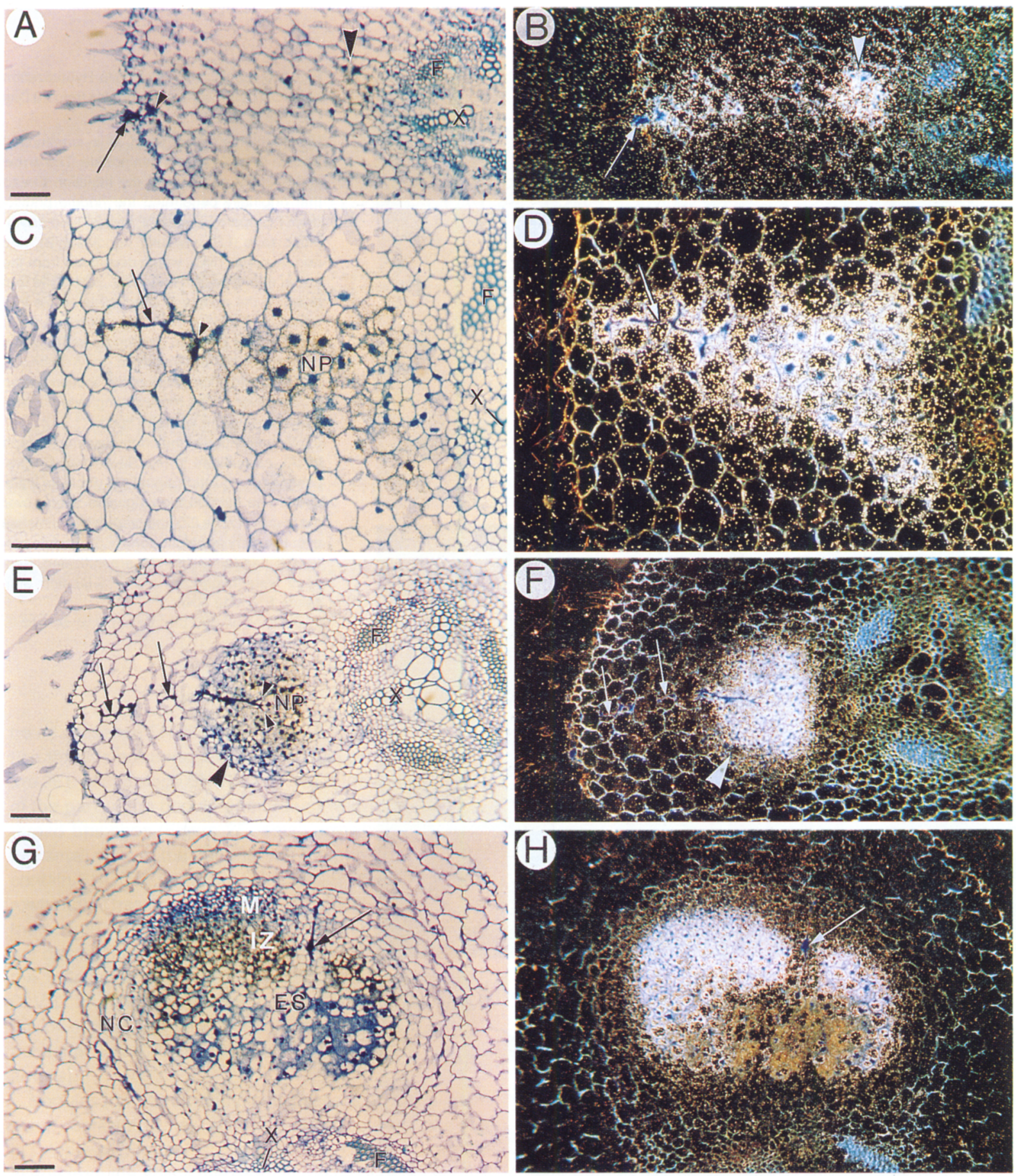

Figure 2. Localization by In Situ Hybridization of ENOD12 Transcripts in Pea Root Segments at Different Stages of Nodule Development

The right panel shows dark-field micrographs corresponding with the bright-field micrographs in the left panel. In the dark-field micrographs, silver grains representing hybridization signal are visible as white spots. $A$ and $B, C$ and $D, E$ and $F$, and $G$ and $H$ represent successive stages of nodule development.

(A) Transection of a 5 day old root, 2 days after inoculation. An infection thread, which is clearly visible at higher magnification, can be observed in a root hair (arrow), the tip of which has reached the second cortical cell layer as deduced by analysis of a complete set of serial sections (small arrowhead). In the inner cortex the site of the future nodule primordium is marked (large arrowhead).

(C) Transection of a 6 day old root, 3 days after inoculation. Infection thread (arrow), infection thread tip located by analyzing a complete set of serial sections (arrowhead), and the nodule primordium (NP) in the root inner cortex are indicated.

(E) Transection of a 7 day old root, 4 days after inoculation. The infection thread (arrows) has reached the nodule primordium (NP) and branches off into several thinner threads (small arrowheads), which grow into cells at the base of the primordium. A few cell layers at the periphery of the primordium, which will most likely develop into the cortex and, at the top, into the apical meristem of the nodule, do not contain hybridization signal (large arrowhead)

(G) Transection of a 10 day old pea root, 7 days after inoculation. The original site of entrance of the infection thread into the nodule primordium is indicated with an arrow. The apical meristem (M), invasion zone (IZ), early symbiotic zone (ES), and nodule cortex (NC) are indicated.

Sections were hybridized with ${ }^{35} \mathrm{~S}$-labeled antisense ENOD12 RNA. Using sense RNA as a probe, we did not observe hybridization signals (data not shown). Bar $=100 \mu \mathrm{m} . X=$ xylem pole, $F=$ phloem fibers of central cylinder. 

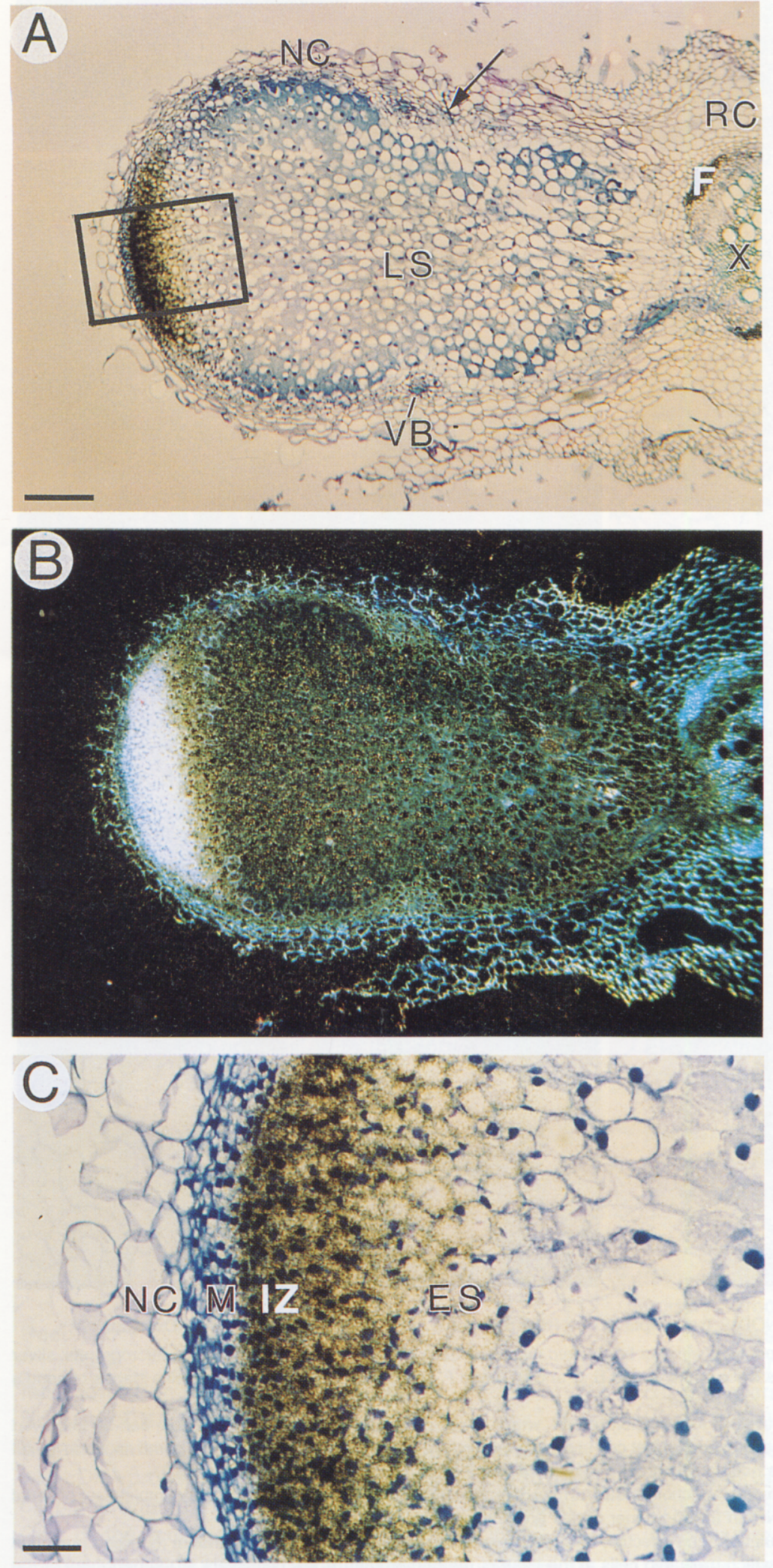

Figure 3. Localization by In Situ Hybridization of ENOD12 Transcripts in Nodules from 20 Day Old Pea Plants

(A) Bright-field micrograph of a longitudinal section of a 20 day old pea nodule. The arrow points to the remnant of the infection thread that originally penetrated the nodule primordium (compare Figures 2E and 2G). Late symbiotic zone (LS), vascular bundles (VB), and nodule cortex (NC), which developed from the apical meristem, are indicated. Part of the root to which the nodule is attached is visible in a transversal section. Here the root cortex (RC), a xylem pole $(X)$, and phloem fibers $(F)$ of the central cylinder are indicated.

(B) Dark-field micrograph of the section shown in (A). Silver grains representing hybridization signal are visible as white spots.

(C) Magnification of the bright-field micrograph in (A), as outlined in (A). Silver grains representing hybridization signal are visble as black spots. The hybridization signal is strong over the invasion zone ( $\mathrm{ZZ}$ ) and gradually diminishes over the early symbiotic zone (ES). Nodule cortex (NC) and meristem (M) are indicated. Sections were hybridized with ${ }^{35}$ S-labeled antisense ENOD12 RNA.

Bar in $A=300 \mu \mathrm{m}$. Bar in $C=50 \mu \mathrm{m}$. 


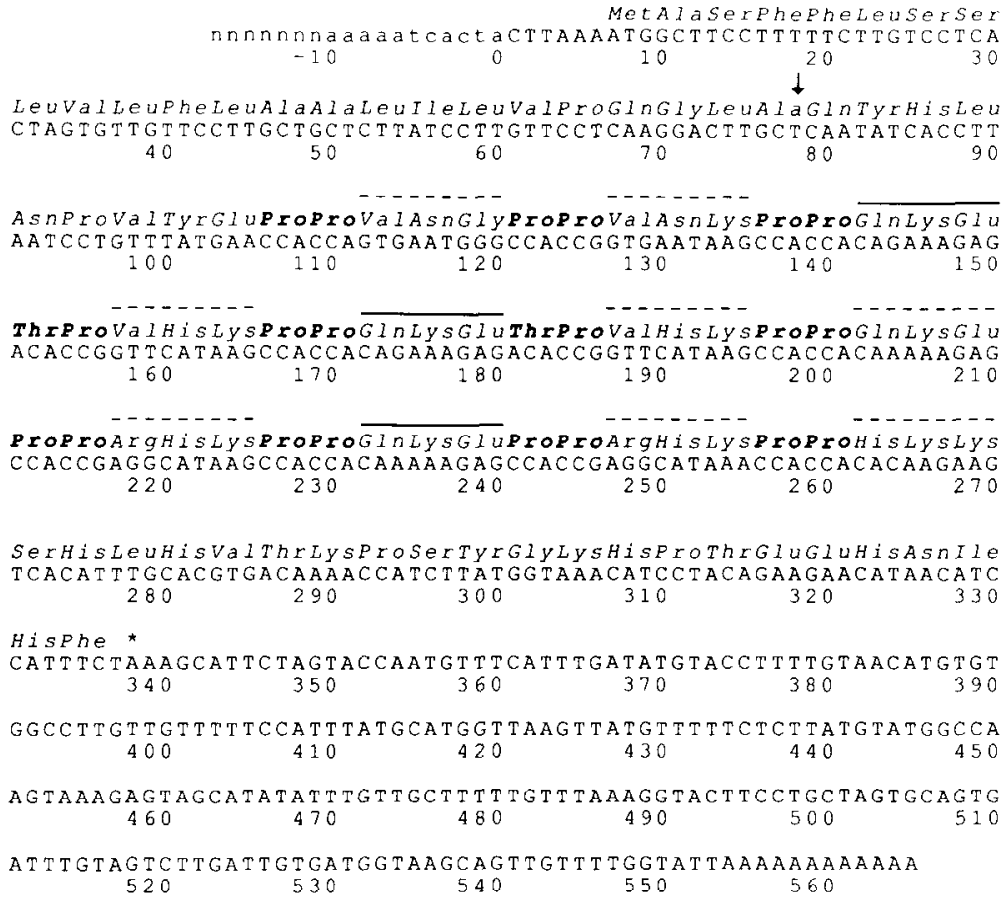

beled antisense ENOD12 mRNA. In 7 day old plants infection threads are penetrating the nodule primordium (Figure 2E). At this stage ENOD12 mRNA is located in all cells of the part of the nodule primordium where the infection thread branches (Figure 2E, small arrowheads). Only a few small cells at the periphery of the primordium do not contain ENOD12 transcript (Figures 2E and 2F, large arrowhead). These cells will form the apical meristem and the nodule cortex, while the other cells of the primordium are destined to become the first cells of the infected and the uninfected cell type (Libbenga and Bogers, 1974; C. V. D. W., unpublished data). In root cortex cells, where the oldest part of the infection thread resides, ENOD12 transcript is no longer detectable (Figures $2 \mathrm{E}$ and $2 \mathrm{~F}$, arrows).

Nodules from 10 day old plants possess an apical meristem, containing small, actively dividing cells that are rich in cytoplasm (Figure 2G). The different tissues are graded in age from the apical meristem to the base of the nodule (Newcomb, 1976). Immediately adjacent to the meristem, in the invasion zone, cells are penetrated by infection threads growing in the reverse direction as they now follow the meristem. About half of the cells in the invasion zone are infected by bacteria released from infection threads. In the early symbiotic zone these cells differentiate into the infected cell type. The other cells that are not infected by rhizobia become the uninfected cell type. ENOD12 transcript is present in the invasion zone, adjacent to the meristem, but is not detectable in the meristematic cells (Figures $2 \mathrm{G}$ and $2 \mathrm{H}$ ). In the early symbiotic zone, where cells are elongating, the concentration of ENOD12 transcript is decreasing.

In nodules from 20 day old plants, ENOD12 mRNA is de-
Figure 4. cDNA and Predicted Amino Acid Sequence of the pPsENOD12 Insert

Nucleotides 1-565 are determined from the pPsENOD 12 insert. Nucleotides -18 to 0 (from the $5^{\prime}$ end of the mRNA) are determined using direct RNA sequencing (see Experimental Procedures). The amino acid sequence of the only long open reading frame is depicted ove the nucleotide sequence. The putative signal peptide cleavage site is marked with an arrow. Prolines in the repeat region are in bold type. The amino acid triplets characteristic of both types of pentapeptide repeats described in the text are overlined with solid and dashed bars respectively. The termination codon ending the reading frame is marked by an asterisk. tectable at the nodule apex (Figures $3 A$ and $3 B$ ). A magnification of Figure $3 A$ shows that the transcript is located in the zone where infection threads are growing (Figure 3C). No transcript is detectable in the meristem, and the concentration of the transcript decreases in the early symbiotic zone. We conclude that in 7 day old as well as in 10 and 20 day old nodules, ENOD12 mRNA is restricted to the region of the nodule where active infection thread growth occurs, and therefore it marks the invasion zone.

\section{ENOD12 Is a Hydroxyproline-Rich Protein}

Further information on the nature of the ENOD12 early nodulin was obtained by determining the nucleotide sequence of the insert of pPsENOD12 (Figure 4). The insert is $553 \mathrm{bp}$ in length, excluding a short poly(A) stretch at the $3^{\prime}$ end of the sequence. The mRNA measures approximately 600 bases, as determined on an RNA transfer blot, and primer extension analysis showed that less than 20 bases from the $5^{\prime}$ end of the mRNA are missing in pPsENOD12 (see Figure 10). The sequence of the $5^{\prime}$ end of the mRNA missing in the CDNA clone was determined by direct RNA sequencing (Figure 4, lowercase letters). The cDNA sequence contains only one long open reading frame, starting with an ATG codon at position 7 , which is the first and only methionine codon in the reading frame. From the derived amino acid sequence, a molecular mass of $12.5 \mathrm{kd}$ was calculated for the ENOD12 protein. A putative signal peptide containing a hydrophobic core sequence is present at the $\mathrm{N}$-terminal part, and the possible cleavage site of the signal peptide, marked with an arrow in Figure 4, was determined by following Von Heijne (1983). The major part of the following protein sequence 


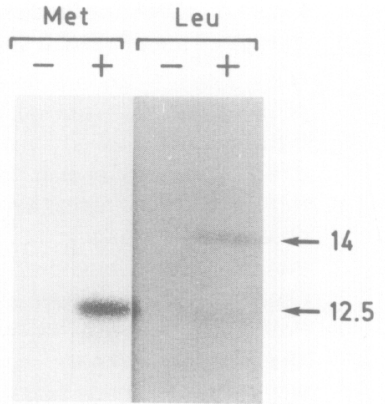

Figure 5. In Vitro Translation Producls of Hybrid-Selected ENOD12 mRNA

ENOD12 mRNA was selected form total nodule RNA and translated in vitro in the presence of $\left[{ }^{35}\right.$ S ]methionine (Met) or $\left[{ }^{3} \mathrm{H}\right]$ leucine (Leu) as radioactive amino acid. Filters used for hybrid selection contained pBR322 (minus sign) or PPsENOD12 insert (plus sign). The right two lanes are exposed 6 -fold longer than the left two lanes. The sizes (kd) of the in vitro translation products are indicated on the right.

consists of two pentapeptide repeating units. One of these units, Pro-Pro-GIn-Lys-Glu, indicated with solid lines, is well conserved throughout the protein sequence. The other unit is present as Pro-Pro-Val-Asn-Gly at the N-terminal part, and gradually every amino acid except the prolines is permuted to give a Pro-Pro-His-Lys-Lys unit at the $\mathrm{C}$-terminal part of the polypeptide chain (dashed lines). At two positions a proline codon is changed into a threonine codon by a single base substitution. Further downstream of the C-terminus, the proline repeat units are absent.

In vitro translation of hybrid-selected ENOD12 mRNA from nodules yielded one radioactive polypeptide of 12.5 $\mathrm{kd}$ when [ ${ }^{35} \mathrm{~S}$ ]methionine was used as radioactive amino acid. When the same selected mRNA was translated in the presence of $\left[{ }^{3} \mathrm{H}\right.$ leucine, two radioactive polypeptides of 12.5 and $14 \mathrm{kd}$ were formed (Figure 5). Since the smaller polypeptide is the one labeled with $\left.{ }^{35} \mathrm{~S}\right]$ methionine, this cannot be a breakdown product of the larger polypeptide. Hence, there appear to be two different ENOD12 mRNAs in nodules. The observation that there is no methionine encoded in the open reading frame of pPsENOD12, except at the start, shows that the cDNA clone corresponds to the mRNA encoding the $14 \mathrm{kd}$ polypeptide, which can only be detected with $\left[{ }^{3} \mathrm{H}\right]$ leucine. The observed discrepancy between the calculated and the apparent molecular weight is rather common for proline-rich proteins (e.g., Franssen et al., 1987).

\section{ENOD12 Gene Expression Requires Rhizobium nod Genes and Is Induced by Excreted Bacterial Compounds}

To determine which bacterial genes are essential for the induction of ENOD12 gene expression, we analyzed the expression of this gene after inoculation with different Rhizobium mutants. The $R$. leguminosarum bv. viciae common nodulation genes nodABC are required for the initiation of cortical cell division, root hair curling, and infection thread formation (Wijffelman et al., 1985). In the R. meliloti-alfalfa interaction, the host-specific nodEF genes

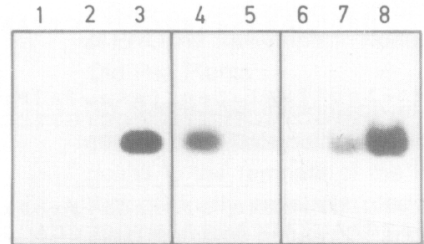

Figure 6. PCR Analysis of ENOD12 Gene Expression in Root Hair RNA

ENOD12 sequences from $1 \mu \mathrm{g}$ of total root hair RNA were amplified using 12 PCR cycles, and after electrophoresis a DNA transfer blot was probed with ${ }^{32}$ P-labeled PPsENOD12 insert. The different lanes contain amplified root hair ENOD12 sequences from uninoculated plants (1 and 6), from plants inoculated with $R$. leguminosarum bv. viciae $A 10$ (2), wild-type R. leguminosarum bv. viciae 248 ( 3 and 8), R. leguminosarum bv. viciae $248^{\mathrm{c}}$ (pMP104) (4), R. leguminosarum bv. viciae $248^{c}$ (pMP104 nodE::TN5) (5), and from plants inoculated with the cellfree supernatant of wild-type R. leguminosarum bv. viciae 248 induced with naringenin (7).

are also important for infection thread formation (Horvath et al., 1986), and recently the involvement of nodEF in infection thread formation has also been demonstrated for the R. leguminosarum bv. viciae-Vicia hirsuta interaction (Van Brussel et al., 1988). Therefore, we examined whether both common and host-specific nod genes are essential for eliciting ENOD12 gene expression in root hairs.

Pea plants were inoculated with various mutant $R$. leguminosarum bv. viciae strains. Wild-type R. leguminosarum bv. viciae 248 was used as a control. To obtain maximum sensitivity in detecting ENOD12 gene expression in root hairs, we amplified cDNA specifically made from total root hair RNA by the polymerase chain reaction (PCR) (see Saiki et al., 1985; Mullis and Faloona, 1987). The amplified cDNA was visualized by DNA transfer blotting using pPsENOD12 cDNA insert as a probe. In this way the presence of ENOD12 transcript in $1 \mu \mathrm{g}$ of total root hair RNA, inoculated with wild-type $R$. leguminosarum bv. viciae, could be visualized within several hours after exposure of a hybridized DNA transfer blot (Figure 6). Upon longer exposure a weak signal could also be observed in uninoculated root hair RNA (not shown). We do not know whether this signal is caused by low levels of ENOD12 mRNA or by residual chromosomal DNA present in the RNA preparations.

The $R$. leguminosarum bv. viciae A10 strain carries a Tn5 mutation in nodA, which blocks the formation of the $\operatorname{nod} A, \operatorname{nod} B$, and nod $C$ products (Wijfelman et al., 1985). In our first experiments we demonstrated by RNA transfer blot analysis that ENOD12 transcript is found in root hairs from plants inoculated with wild type $\mathrm{R}$. leguminosarum bv. viciae, but not in root hairs from plants inoculated with R. leguminosarum bv. viciae A10 (Figure 1B). Using the more sensitive PCR method, it was confirmed that a mutation in nodA abolished the ability of bacteria to induce ENOD12 gene expression in root hairs (Figure 6, compare lanes 2 and 3).

The Sym plasmid cured R. leguminosarum bv. viciae 


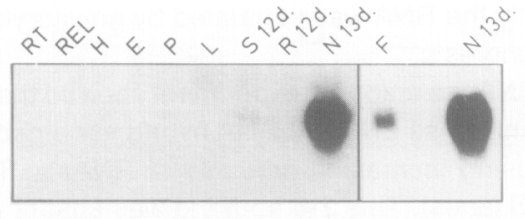

Figure 7. RNA Transfer Blot Analysis of Various Uninoculated Pea Tissues

RNA transfer blots contain $20 \mu \mathrm{g}$ of total RNA from the following tissues; from 5 day old pea plants: root tip (RT), root elongation zone (REL), hypocotyl $(H)$, epicotyl $(E)$, plumule $(P)$, leaf $(L)$; from 12 day old pea plants: stem (S), root $(R)$; nodules 13 days after inoculation $(N)$; and from plants of varying age: flower $(F)$. Blots were probed with pPsENOD12 insert; in lanes $P$ to $N$ in the left panel, a faint band migrating with lower mobility than ENOD12 mRNA can be observed; this band represents aspecific binding of probe to the small ribosomal RNA.

$248^{c}$ (pMP104) strain, carrying the nodEFDABClJ genes on the low-copy plasmid pMP104, is capable of nodulating Vicia (Spaink et al., 1987) and pea (H. P. Spaink, personal communication). This strain was able to induce ENOD12 gene expression (Figure 6, lane 4). On the other hand, the R. leguminosarum bv. viciae $248^{c}$ (pMP104 nodE::Th5) strain, which carries a mutation in nodE and forms no infection threads on Vicia (Van Brussel et al., 1988), showed no induction of ENOD12 gene expression (Figure 6, lane 5). We concluded that both common and host-specific nod genes of Rhizobium are essential for eliciting ENOD12 gene expression in pea plants.

It has been shown that, upon induction of the nod genes with a flavonoid, rhizobia excrete compounds that cause deformation of root hairs (Zaat et al., 1987). Therefore, we studied whether the bacteria also excrete compounds capable of inducing the ENOD12 gene. Rhizobia were grown in the presence or absence of naringenin, a flavonoid inducing the nod genes. After removal of the bacteria (see Experimental Procedures), the Rhizobium-free culture medium was applied to 3 day old pea seedlings. Two days after inoculation root hairs were harvested, and the presence of ENOD12 mRNA in root hair RNA was studied. The ENOD12 transcript was detectable in root hair RNA from plants treated with the medium of bacteria cultured in the prosence of naringenin (Figure 6, lane 7). On the other hand, the culture media of bacteria grown in the absence of naringenin could not establish an increase in the amount of transcript (data not shown). We concluded that excreted compounds formed after induction of the Rhizobium nod genes are able to elicit ENOD12 gene expression in root hairs.

ENOD12 Gene Expression Is Not a Defense Reaction The proline repeat units in the ENOD12 protein are quite similar to those in the amino acid sequence of hydroxyproline-rich glycoproteins, accumulating in plant tissue after wounding or upon interactions with pathogens (Chen and Varner, 1985; Corbin et al., 1987). Furthermore, infection thread formation has been viewed as a modified plant defense response (Vance, 1983; Djordjevic et al., 1987). This prompted us to investigate whether the ENOD12 gene or similar genes are induced as part of a defense response in pea. For these experiments we used the pathogenic fungus Fusarium oxysporum f. sp. pisi. While accumulation of hydroxyproline-rich glycoprotein transcripts was observed upon RNA transfer blot analysis of total RNA from pea roots inoculated with the fungus, no ENOD12 mRNA was detectable in these RNA preparations (data not shown). We can therefore conclude that the expression of the ENOD12 gene(s) during the infection process cannot be attributed to a general defense response following Rhizobium infection.

\section{ENOD12 Gene Expression in Stem and Flower}

We studied whether the ENOD12 gene(s) resembling ENOD12 is expressed in other parts of the plant since this might give some clues on the evolutionary origin of the ENOD12 early nodulin. By RNA transfer blot analysis we were unable to detect ENOD12 transcripts in root tip, root elongation zone, mature root, hypocotyl, epicotyl, plumule, and leaf (Figure 7). On the other hand, hybridizing RNA similar in size to ENOD12 transcript, but less abundant, was found in stem and flower RNA (Figure 7). In both tissues this RNA was also detectable with an ENOD12 probe, pPsENOD12-3', containing only the $3^{\prime}$ region downstream from the Bgll site at position 239 in the cDNA sequence (see Figure 4; data not shown).

Using the in situ hybridization technique, we localized ENOD12 mRNA in stem internode sections. The transcript appeared to be located in a zone of cortical cells surrounding the central ring of vascular bundles and the interfascicular cambium cells (Figure 8). We were not able to localize the ENOD12 transcript unambiguously in flowers.

In vitro translation of hybrid-selected ENOD12 nodule mRNA resulted in two distinct polypeptides, as shown in Figure 5. Therefore, the existence of two or more ENOD12 genes in the pea genome seemed plausible. To obtain information on the number of ENOD12 genes, we performed Southern blot analyses of restricted pea genomic DNA using the CDNA clones pPsENOD12 and pPsENOD12-3' as probes. Two EcoRl fragments of 4.5 and $5.5 \mathrm{~kb}$ hybridized to pPsENOD12. Both fragments also hybridized to the $3^{\prime}$ region probe. Restriction with Hindlll again yielded two fragments, 1.8 and $7 \mathrm{~kb}$ in size, hybridizing just as well to pPsENOD12 as to the $3^{\prime}$ region probe (data not shown). Since the two HindlII and the two EcoRl fragments hybridized to the same level with both pPsENOD12 and pPSENOD12-3', it appears very likely that there are two ENOD12 genes in the pea genome.

The presence of more than one ENOD12 gene raises the question of which genes are transcribed in the different tissues. To answer this question we could not use in vitro translation of hybrid-selected ENOD12 mRNA from stem and flower, since in our hands the sensitivity of hybrid-released translation was insufficient with low abundant mRNA and $\left.{ }^{3} \mathrm{H}\right]$ leucine as the labeled amino acid. Specific probes for different transcripts could not be used either, since all isolated ENOD12 cDNA clones corresponded to the same ENOD12 mRNA. Therefore, we adapted the RNAase mapping assay (Melton et al., 1984) 


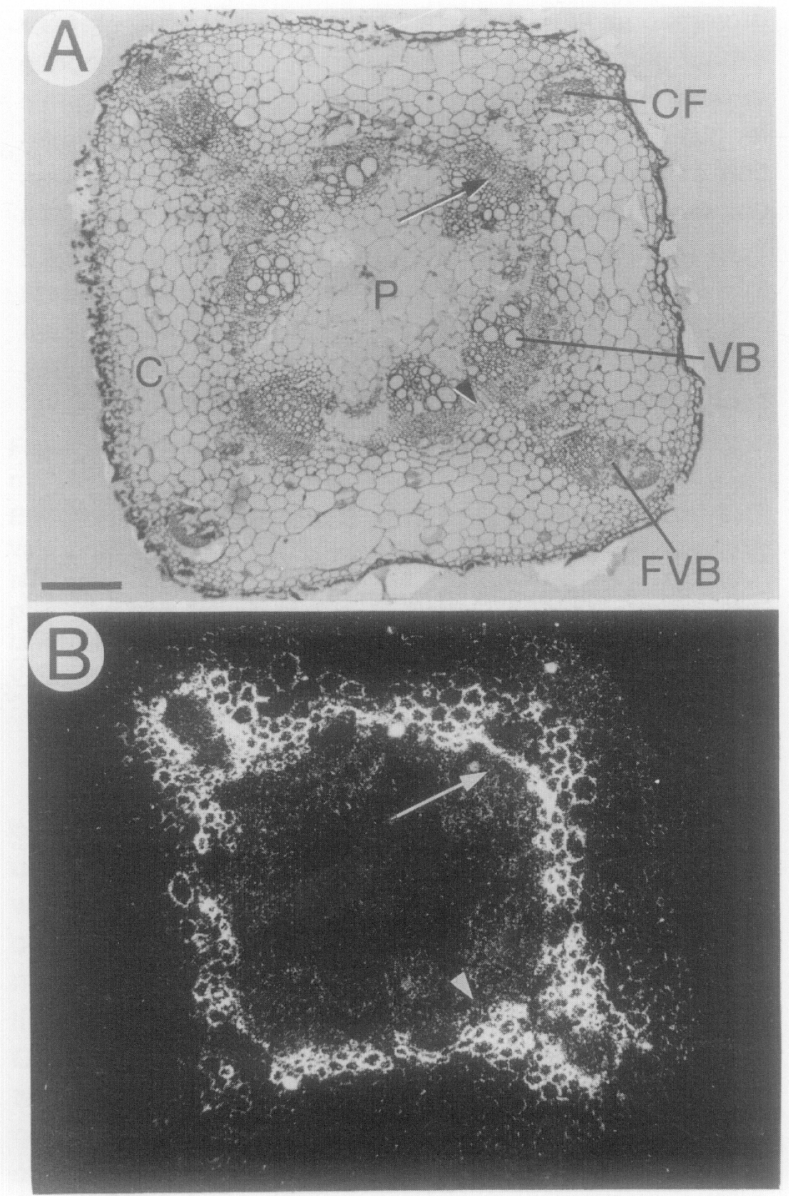

Figure 8. Localization of ENOD12 Transcripts in Stem Tissue by In Situ Hybridization

(A) Bright-field micrograph of a transection of the fourth internode of a 24 day old pea plant, showing a central ring of vascular bundles (VB) with two fibrovascular bundles (FVB) and two cortical fiber bundles (CF) traversing the cortex (C). P, pith; arrow, fascicular cambium; arrowhead, interfascicular cambium.

(B) Dark-field micrograph of the same section as in (A). Silver grains representing hybridization signal are visible as white spots. The section was hybridized with ${ }^{35}$ S-labeled ENOD12 antisense RNA. Bar $=$ $300 \mu \mathrm{m}$.

to discriminate between different mRNAs by virtue of their complete or incomplete protection to RNAase digestion. We used the $3^{\prime}$ region of the pPsENOD12 insert as a probe for RNAase mapping, since the $5^{\prime}$ region contains sequence duplications that prevent accurate mapping. ${ }^{32} \mathrm{P}-$ labeled antisense ENOD12 RNA was transcribed from the $3^{\prime}$ region of the insert of pPsENOD12, as indicated in Figure $9 \mathrm{C}$ (1 and 2). This antisense RNA was hybridized to total RNA from roots and nodules or to root RNA. This root RNA was mixed with $1 \mathrm{ng}$ of unlabeled ENOD12 sense RNA transcribed from the $3^{\prime}$ region of the insert of pPsENOD12, which was cloned in the opposite orientation toward the T7 promoter as indicated in Figure 9C (3). After hybridization, single-stranded RNA was digested using increasing amounts of RNAase T1, and sub- sequently the RNA was separated by polyacrylamide gel electrophoresis.

The RNAase mapping experiment showed that a $216 \mathrm{bp}$ sense-antisense ENOD12 RNA hybrid remained fully protected using increasing amounts of RNAase T1 (Figure $9 A, R+S$ lanes). This 216 bp band was absent when root RNA was hybridized to antisense ENOD12 RNA (Figure 9A, $R$ lanes). Hybridization of the antisense probe to nodule RNA and subsequent digestion resulted in a fully protected hybrid of 202 bp (Figure 9A, N lanes $1 / 5 \mathrm{~T}$ and 1 T), which was the expected size, as indicated in Figure 9C. Using low concentrations of RNAase $\mathrm{T} 1$, the trimming of the fully protected hybrid was still incomplete, resulting in products ranging in size from 202 to 220 bp (Figure 9A, $\mathrm{N}$ lane 1/25 T). In addition to the fully protected $202 \mathrm{bp}$ hybrid, partially protected hybrids were formed (Figure 9A, $\mathrm{N}$ lanes). Since these hybrids were not formed when the ENOD12 sense RNA was hybridized to the antisense probe (Figure 9A, R+S lanes), we conclude that they originate from the second ENOD12 mRNA that occurs in nodules. Using increasing amounts of RNAase, many of these heterologous hybrids were degraded to smaller molecules, which cannot be analyzed on sequence gel as their size corresponds to the size of the fragments generated by digestion of the excess antisense RNA probes. However, the 74 and 48 bp fragments (Figure 9A, N lanes) are examples of fragments that are not further degraded by increasing RNAase concentrations.

In conclusion, at fixed RNAase concentration, identical digestion patterns of the heterologous ENOD12 hybrid were obtained in different, independent experiments using nodule RNA from two different pea cultivars (Figures $9 A$ and $9 B, N$ lanes). This indicates that with the RNAase mapping method, partially protected hybrids formed by hybridization of the antisense probe to a nonhomologous mRNA are reproducibly detected as specific fragments on a polyacrylamide gel. We concluded that RNAase $\mathrm{T} 1$ mapping is useful for distinguishing between different mRNAs.

Using this RNAase mapping method, we analyzed RNA from stem and flower to determine which ENOD12 mRNAs occur in these tissues. We also analyzed root hair RNA to investigate whether both ENOD12 mRNAs detected in nodule are already present at the early stages of infection thread formation. The 202 bp full-size protected hybrid as well as the 75 and 48 bp bands, specific for the partially degraded hybrid, are present in the RNAase protection pattern of stem and root hair RNA as shown in Figure 9B ( $S$ and $\mathrm{RH}$ lanes). This indicates that in these parts of the plant, the same ENOD12 mRNAs are present as in nodules. Using flower RNA we could visualize the full-size protected hybrid, indicating that mRNA corresponding to the isolated pPSENOD12 clone is present in flower tissue. We could not demonstrate in this experiment, nor in experiments using more flower RNA and prolonged exposures, the presence of both the 75 and 48 bp bands originating from the protected heterologous ENOD12 mRNA.

Long exposures, as in Figure 9B, always revealed the presence of 216 and 212 bp fragments in all lanes includ- 

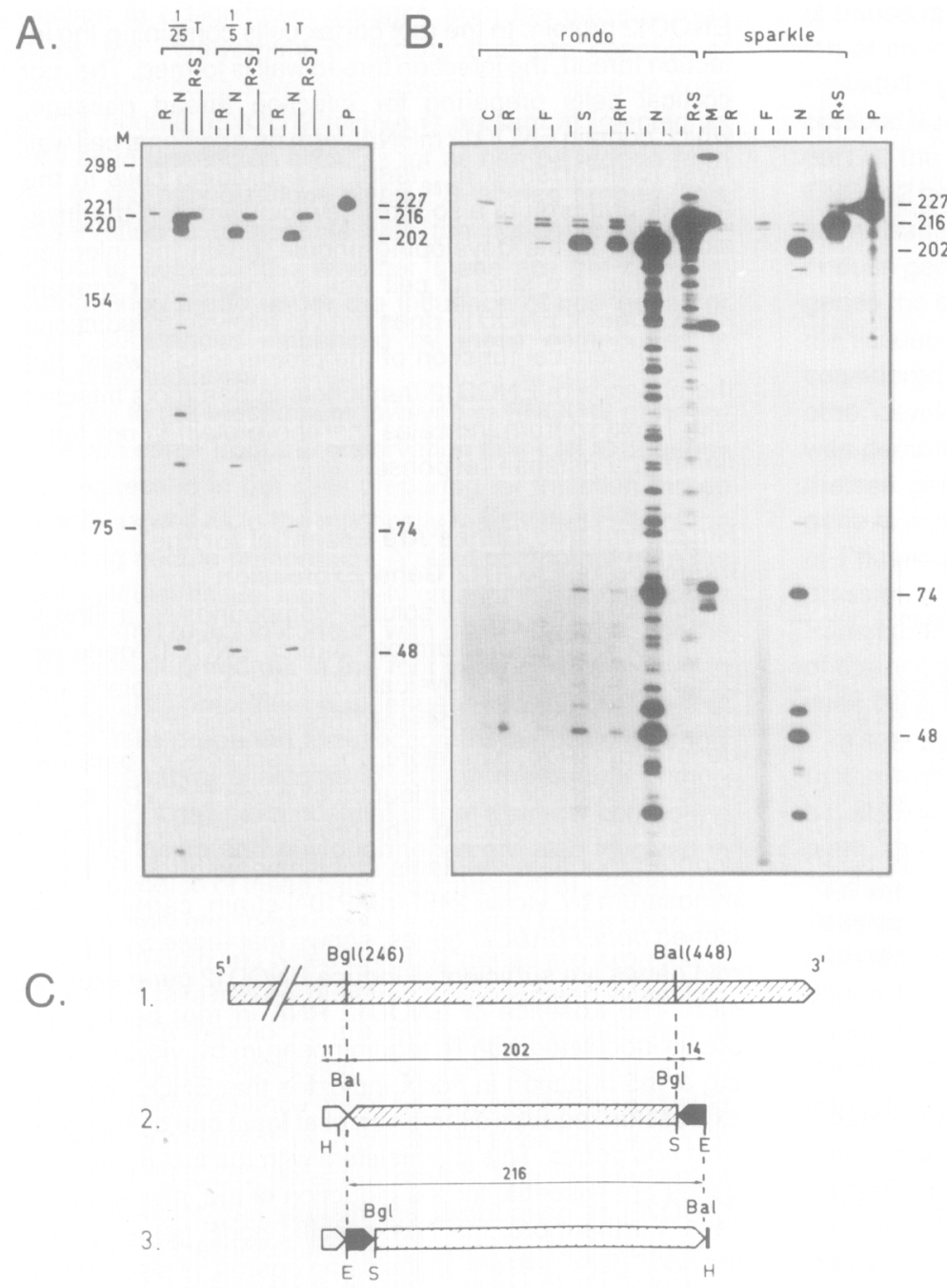

Figure 9. RNAase Mapping of ENOD12 Transcripts in Nodule, Stem, Root Hair, and Flower Tissues

(A) $20 \mu \mathrm{g}$ of total RNA from 8 day old roots (R), nodules 13 days after inoculation $(N)$, and roots mixed with $1 \mathrm{ng}$ of sense ENOD12 RNA transcribed from a T7 RNA polymerase vector (C, part 3) $(R+S)$ were hybridized to a 227 nucleotide antisense ENOD12 RNA probe (C, 2), followed by digestion with varying amounts of RNAase T1 (1/25 T: $228 \mathrm{U} / \mathrm{ml} ; 1 / 5 \mathrm{T:} 1140 \mathrm{U} / \mathrm{ml}$; and $1 \mathrm{~T}: 5760 \mathrm{U} / \mathrm{ml}$ ). Protected RNA molecules were separated by electrophoresis on a $6 \%$ polyacrylamide-urea gel, and sizes were compared with pBR322 $\times$ Hinfl size markers $(M)$ and the input ENOD12 RNA probe $(\mathrm{P})$. Vertical bars above represent the borders of the different lanes.

(B) $20 \mu \mathrm{g}$ of total RNA from 8 day old roots (R), flowers (F), fourth internode stem sections from 35 day old plants (S), root hairs $48 \mathrm{hr}$ after inoculation $(\mathrm{RH})$, nodules 13 days after inoculation (N), and root plus $1 \mathrm{ng}$ of sense ENOD12 RNA $(R+S)$ were hybridized to antisense ENOD12 RNA probe $(P)$ as in $(A)$, followed by digestion with $5760 \mathrm{U} / \mathrm{ml}$ RNAase $\mathrm{T} 1$ and electrophoresis on a $6 \%$ polyacrylamide-urea gel. Root, flower, and nodule RNA was taken from two different cultivars, $\mathrm{Cv}$. rondo and $\mathrm{cv}$. sparkle. A small portion of root RNA immediately after hybridization with probe, without RNAase digestion $(C)$, and pBR322 $\times$ Hinfl size markers $(M)$ were also subjected to electrophoresis. Vertical bars above represent borders of the different lanes.

(C) 1: Schematic representation of the cloned ENOD12 mRNA. The positions of the restriction sites in the corresponding cDNA clone that were used to subclone the fragment used for RNAase mapping is indicated. 2 and 3: Sequences present in the ENOD12 antisense (2) and sense (3) T7 RNA transcripts: 202 nucleotides between the Bgll site at position 246 and the Ball site at position 448 in the PPSENOD12 CDNA (1) (cross-hatched); 11 nucleotide T7 RNA polymerase promoter region (solid white); and 14 nucleotide pT7 polylinker (solid black). Complementary sequences are indicated by identically shaded inversed arrows. Dashed vertical lines depict the size of the hybridizing fragments upon hybridization of the antisense RNA probe to the homologous ENOD12 mRNA (202 nucleotides) and to the sense RNA transcript (216 nucleotides), respectively.

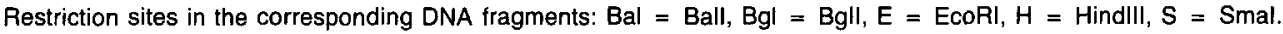

ing the root lane. The concentration of these fragments was dependent on the amount of prohe input and not on the amount of hybridizing mRNA in the total RNA preparations. Therefore, they are not due to the formation of a hybrid between probe and ENOD12 mRNA.

Since we could not detect differences among the ENOD12 mRNAs present in nodule, stem, and flower using RNAase mapping with the $3^{\prime}$ region of PPsENOD12, we investigated whether differences were detectable at the $5^{\prime}$ end of the ENOD12 mRNA in the different tissues. We extended a synthetic primer complementary to nucleotides 70-90 of the pPSENOD12 insert. After hybridizing with nodule, stem, and flower RNA, we compared the size of the extension products, as shown in Figure 10 (lanes $\mathrm{S}$ and $\mathrm{N}$ ). The sizes of the extension products with stem and nodule RNA appeared to be identical. Hence, no difference in size of the $5^{\prime}$ ends can be detected with this primer. In contrast, the extension products with flower RNA differed in size (Figure 10, lane F). The largest extension product with flower RNA measured 16 nucleotides more compared with the largest extension product with nodule RNA. This suggests that different transcriptional start sites are used on the gene corresponding to pPsENOD12 in flower and nodule or alternatively, the RNA transcript is differentially spliced at the $5^{\prime}$ end in these tissues.

\section{Discussion}

\section{The ENOD12 Gene Product Is Involved} in the Infection Process

The data presented in this paper demonstrate that the cDNA clone pPsENOD12 represents a novel gene encoding a hydroxyproline-rich early nodulin involved in the in- 


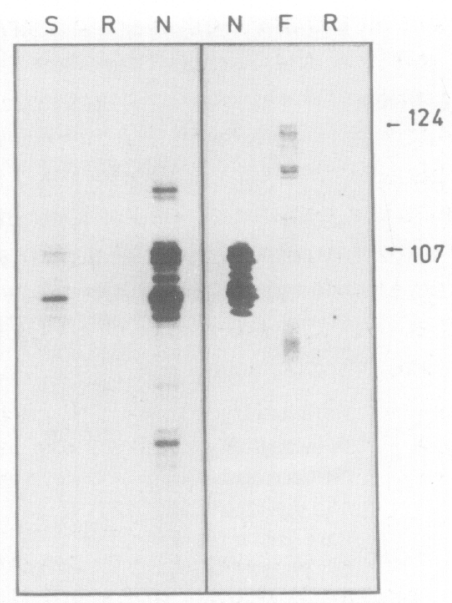

Figure 10. Primer Extension Analysis of ENOD12 mRNA from Nodule, Stem, and Flower

An end-labeled oligonucleotide complementary to nucleotides $70-90$ of the CDNA sequence was annealed to total RNA from: fourth internode stem sections from 35 day old plants $(S), 8$ day old roots $(R)$ nodules 13 days after inoculation $(N)$, and flowers $(F)$, extended with reverse transcriptase and subjected to electrophoresis on $6 \%$ polyacrylamide-urea gels. Twenty micrograms of total RNA was used for each extension, except in the extensions shown in the right panel where $80 \mu \mathrm{g}$ of total RNA from flowers and roots was used. The size of the largest reproducible extension fragment in each of the lanes is indicated on the right (nucleotides) to indicate the size differences between the two groups of extension products.

fection process that is part of the pea-Rhizobium interaction. The expression of the ENOD12 gene in root hairs requires the presence of functional nod genes in Rhizobium. Therefore, pPsENOD12 can help analyze the mechanism by which the bacterial nod genes initiate the infection process.

Previously, three cloned soybean early nodulins, GmENOD2, GmENOD13, and GmENOD55, have been shown to be involved in steps in nodule morphogenesis but not in the infection process (Franssen et al., 1987, 1988). Likewise, the alfalfa and pea ENOD2 early nodulins are involved in nodule formation but not in the infection process (Dickstein et al., 1988; Van De Wiel et al., 1990). These early nodulins from soybean, alfalfa, and pea are all hydroxyproline-rich proteins. Strikingly, the infection-related ENOD12 early nodulin is also proline-rich. As in the ENOD2 early nodulins from different species and in GmENOD13, the major part of the ENOD12 protein is composed of repeating elements containing 3 amino acids interspersed with two or three prolines. The structure of these three early nodulins is very similar to the soybean cell wall protein 1A10 (Averyhart-Fullard et al., 1988). Because of the homology between $1 \mathrm{~A} 10$ and ENOD12, we assume that ENOD12 is also a cell wall protein involved in the infection process. The occurrence of a putative signal peptide, which might function in excreting the protein, is consistent with this hypothesis.

All root and nodule cells in which we have found ENOD12 transcript are sites of new cell wall synthesis and are therefore possible sites of incorporation of the
ENOD12 protein. In the root cortex cells containing the infection thread, the infection thread wall is formed. The root cortical cells preparing for infection thread passage, which contain ENOD12 mRNA, form an additional cell wall layer (Bakhuizen et al., 1988). The dividing cells in the nodule primordium also form new cell walls. In the invasion zone of the developing nodule, again the infection thread tips are sites of cell wall synthesis. Our present knowledge of ENOD12 does not yet allow for predictions of a biochemical function of the protein in cell walls, but the absence of ENOD12 transcripts in pea roots infected with $F$. oxysporum indicates that the protein is not functional in a defense response.

\section{Rhizobium nod Genes Are Essential for the Induction of ENOD12 Gene Expression}

Our observation that soluble compounds in a Rhizobium-free culture medium can induce ENOD12 gene expression shows that physical contact between plant and bacterium is not a necessary prerequisite for ENOD12 gene expression. Therefore, the direct role of bacterial genes in producing compounds involved in ENOD12 expression can be studied. The presence of ENOD12 transcript in root hairs of plants inoculated with the R. leguminosarum bv. viciae $248^{c}$ (pMP104) strain, carrying only cloned nodEFDABCIJ genes, shows that these Sym plasmid genes are sufficient to induce ENOD12 gene expression. The absence of ENOD12 RNA in root hairs from plants inoculated with $R$. leguminosarum bv. viciae carrying a Tn5 mutation in nodA indicates that ENOD12 gene expression requires expression of at least one of the common nod genes. This is consistent with the fact that these genes are essential for the induction of the infection process. Furthermore, the host-specific nodE gene, and/or the nod $F$ gene present on the same operon, is also essential. Hence, both common and host-specific nod genes appear to be involved in producing the factor(s) that elicits ENOD12 gene expression.

The R. meliloti nod $A$ and nodB genes have been shown to be involved in generating small soluble compounds that stimulate mitosis of plant protoplasts (Schmidt et al., 1988). Faucher et al. (1989) reported that R. meliloti common nod genes are essential for the production of root hair deformation factor and that the nodH gene is involved in determining the host specificity of this factor. These authors hypothesize that the common nod genes produce a compound that can be modified to different factors: e.g., to root hair deformation factor by the nodH gene product. Whether the compound(s) inducing ENOD12 gene expression is also the result of a modification of a nodABC dependent factor by the nodE product or whether nod $A B C$ and $n o d E$ enable production of different factors that are both necessary for induction of ENOD12 gene expression cannot yet be decided.

Which molecular mechanisms lead to ENOD12 gene expression? We have shown that soluble compounds from Rhizobium that are excreted upon induction of the nod genes are the trigger in inducing expression of the early nodulin gene. Induction occurs in front of the growing infection thread and in the nodule primordium. This in- 
duction at a significant distance from the bacteria indicates the involvement of factors that are capable of diffusing through several cell layers. In the invasion zone of the nodule, ENOD12 mRNA is present in infected as well as in uninfected celis, as far as can be judged from our in situ hybridizations using ${ }^{35} \mathrm{~S}$-labeled probes. This observation is compatible with the notion of diffusible inducing compounds. Whether these are the bacterial compounds made under the influence of nod genes or plant substances influenced by these compounds is presently unknown.

Clues to the mechanism involved in ENOD12 gene expression come from the observation that ENOD12 genes are expressed in the cells preparing for infection thread growth as well as in the mitotically reactivated cells of the initiating nodule primordium. A plant compound from the root vascular tissue, most likely present in the xylem, has been found to act in concert with plant hormones for the induction of primordia in the root inner cortex, similar to the nodule primordium (Libbenga et al., 1973). The root cortex cells preparing for infection thread passage show many structural analogies to cells in the nodule primordium, and it has been postulated that a similar compound from the xylem and phytohormones are also involved in the preparation of these cells (Bakhuizen et al., 1988). The analogy between these cells is supported by our observation that in both cell types ENOD12 genes are expressed. Hence, we take into account that the postulated xylem factor and plant hormones are involved in the induction of ENOD12 gene expression. The necessary changes in phytohormone balance might be induced by the excreted bacterial compounds we have shown to be involved in induction of ENOD12 gene expression. The involvement of a xylem factor can explain the distribution of ENOD12 mRNA from the infection thread toward the nodule primordium near a xylem pole, at early stages of the infection process.

ENOD12 Gene Expression in Stem and Flower Tissue An important question concerning the evolutionary origin of the ENOD12 genes active in the Rhizobium infection process is whether the ENOD12 mRNAs in stem and flower are transcribed from the same genes. From Southern analysis and hybrid-released translation experiments, we conclude that two genes are present in the pea genome, and they are both transcribed in nodules. Since the occurrence of these two mRNAs in stem and flower tissue could not be analyzed by standard means, we successfully modified an RNAase mapping procedure to distinguish between different ENOD12 transcripts. In general, this method might be a useful tool to analyze differential transcription of gene families, since extensive cDNA cloning is not required. In summary, the conclusions from our RNAase mapping and primer extension experiments are that both ENOD12 genes are expressed in nodule and stem tissue, whereas in flower tissue the expression of only one gene, corresponding to pPsENOD12, can be detected. The $5^{\prime}$ end of this mRNA differs from that of its homologous counterpart in nodule. We assume that the difference in nodule and flower is due to a different start of transcription on the same gene or by alternative splicing of an intron near the $5^{\prime}$ end.

Nodulin genes are by definition genes exclusively expressed during root nodule formation and not in any other part of the plant (Van Kammen, 1984). Our finding that ENOD12 genes are expressed at a low level in flower and stem tissue shows that the ENOD12 genes are not true nodulin genes. However, in most other studies on nodulin genes the analyses have been restricted to root and nodule tissues. One can therefore expect that several genes considered to represent true nodulins are also used in other developmental programs in the plant. Recently, this was demonstrated for the nodule-specific glutamine synthetase gene. More detailed analyses showed that this gene is expressed at low levels in, for example, the stem of Phaseolus plants (Bennett et al., 1989). Also, the expression of a globin gene in both roots and nodules from Parasponia suggests that leghemoglobin, the "archetype" of the nodulins, might be expressed in nonsymbiotic tissues (Bogusz et al., 1988).

In conclusion, nodule formation involves not only genes that are specifically evolved for the benefit of symbiosis, but also genes that are normally used in other parts of the plant, as exemplified by the ENOD12 genes in pea and the "nodule-specific" glutamine synthetase gene in bean. These genes are not expressed in uninoculated roots, and therefore their expression must be directly or indirectly induced by Rhizobium factors. It becomes an intriguing question whether Rhizobium is exploiting the regulatory mechanisms used in other parts of the plant or whether new symbiotic regulatory mechanisms have evolved.

\section{Experimental Procedures}

\section{Plant Materials}

Pea (Pisum sativum L. cv. rondo or sparkle) plants were cultured and inoculated with $R$. leguminosarum bv. viciae 248 as described by Bisseling et al. (1978). Nodules were excised from root tissue, except in the case of pea plants, 8 days after inoculation when $2.5 \mathrm{~cm}$ sections of the main root, where nodules would appear, were harvested. Uninfected pea plants were cultured in the same way, and pieces of the main root were collected 8 days after sowing. Pea root hairs were brushed from the main root of seedlings $48 \mathrm{hr}$ after inoculation of 3 day old seedlings, as described by Gloudemans et al. (1989).

F. oxysporum mycelium was inoculated in Czapek-dox medium and grown for 2 days at $30^{\circ} \mathrm{C}$. Pea plants were inoculated with this suspension 3 days after sowing and were cultured as above. Root tissue was harvested after various incubation times. All plant tissues were frozen in liquid nitrogen immediately after harvesting and stored at $-70^{\circ} \mathrm{C}$.

\section{Preparation of Rhizobium-Free Culture Medium}

Bacteria-free culture medium for the inoculation of plants was prepared as follows: $R$. leguminosarum bv. viciae 248 was grown in YMB medium to late log phase, diluted to $O D_{600}=0.01$ in minimal medium and grown to late log phase, and diluted again 1:100 in plant medium containing $2 \mu \mathrm{M}$ naringenin. Bacteria were then grown to $O D_{600}=$ 0.3. The culture was centrifuged, and the supernatant was treated with chloroform and inoculated on 3 day old pea seedlings.

\section{cDNA Cloning}

A גgt11 cDNA library, prepared from Pisum sativum cv. sparkle nodule RNA of 21 day old plants, was kindly provided by Dr. G. Coruzzi (Tigney et al., 1987). Nitrocellulose replicas were made, containing phage DNA of approximately $\mathbf{3 0 0 0}$ plaques, using standard procedures (Maniatis et al., 1982). ${ }^{32}$ P-labeled cDNA probes were prepared from poly $(A)^{+}$ 
RNA of nodules from 10 day old plants and of 8 day old uninoculated roots. Replica filters were hybridized to either root or nodule cDNA as described by Franssen et al. (1987). Plaques giving a nodule-specific signal were purified, phage DNA was isolated, and cDNA inserts were subcloned into pUC vectors using standard procedures (Maniatis et al., 1982).

\section{RNA Expression Analyses}

Total RNA from nodules and other tissues was isolated by phenol extraction and $\mathrm{LiCl}$ precipitation according to De Vries et al. (1982). Total RNA concentrations were measured spectrophotometrically. Equal amounts of total RNA, as indicated in the Figure legends, were subjected to gel electrophoresis. RNA transfer blotting was performed as described by Franssen et al. (1987), using GeneScreen membranes as support. Blots were hybridized to nick-translated cDNA inserts.

\section{Genomic DNA Isolation and Blotting}

Genomic DNA from pea leaves was isolated using the CTAB method described by Rogers and Bendich (1988). Restriction enzyme digestions were performed under standard conditions. Digested DNA was electrophoresed on a 1\% agarose gel and transferred to GeneScreen plus membranes (New England Nuclear Corp.) using ammonium acetate transfer (Rigaud et al,, 1987). The blot was hybridized to nicktranslated cDNA insert in $1 \mathrm{M} \mathrm{NaCl}, 1 \%$ SDS, $10 \%$ dextran sulphate, and $100 \mu \mathrm{g} / \mathrm{ml}$ denatured salmon sperm DNA at $65^{\circ} \mathrm{C}$ for $24 \mathrm{hr}$. Subsequently, blots were washed twice for $10 \mathrm{~min}$ in $2 \times \mathrm{SSC}$ and twice for $20 \mathrm{~min}$ in $2 \times \mathrm{SSC}-1 \%$ SDS at $65^{\circ} \mathrm{C}$.

\section{Hybrid-Released Translation}

Selection of ENOD12 mRNA was performed with the insert of pPsENOD12 bound on diazophenylthio paper (Bio-Rad) as described by Maniatis et al. (1982). Denatured DNA $(50 \mu \mathrm{g})$ was spotted on diazophenylthio discs of $0.5 \mathrm{~cm}^{2}$. Hybridization to $1 \mathrm{mg}$ of total nodule RNA from 12 day old plants was performed in $300 \mu$ containing $50 \%$ ( $v / v$ ) formamide, $0.1 \%$ SDS, $0.6 \mathrm{M} \mathrm{NaCl}, 4 \mathrm{mM}$ EDTA, $80 \mathrm{mM}$ Tris- $\mathrm{HCl}$ $(\mathrm{pH} 7.8)$. Hybridization was initiated at $50^{\circ} \mathrm{C}$, and the temperature was decreased to $37^{\circ} \mathrm{C}$ over a $6 \mathrm{hr}$ period. Hybrid-selected mRNA was translated in a wheat germ extract (Bethesda Research Laboratories) using [ $\left.{ }^{35} \mathrm{~S}\right]$ methionine or $\left[{ }^{3} \mathrm{H}\right]$ leucine (New England Nuclear Corp.) as radioactive amino acid. Proteins were separated on SDS containing $25 \%$ acrylamide gels. Gels were fluorographed to Kodak XAR-5 films.

\section{DNA Sequencing}

pPsENOD12 insert was sequenced using the double-stranded dideoxy chain termination procedure (Korneluk et al., 1985). Both strands were sequenced entirely. In addition, the insert of a second, independently obtained ENOD12 clone was sequenced, spanning nucleotides 16565 of the sequence in Figure 3 . Sequence data were stored and analyzed using programs written by R. Staden on VAXNMS and microVAXNMS computers.

\section{In Situ Hybridization}

In situ hybridization was performed essentially as described by Cox et al. (1984), following a protocol kindly provided by Dr. M. van Montagu and Dr. G. Engler.

The insert of pPSENOQ12 was cloned in pT76 (kindty provided by Dr. S. Tabor), and antisense RNA probes were transcribed using T7 ANA polymerase (New England Biolabs) and [35S]UTP (New England Nuclear Corp.) (1000-1500 Ci/mmol) as the radioactive nucleotide. Unlabeled UTP was not added. The probes were partially degraded to an average length of 150 nucleotides by heating for $90 \mathrm{~min}$ at $60^{\circ} \mathrm{C}$ in a buffer containing $0.2 \mathrm{M} \mathrm{Na}_{2} \mathrm{CO}_{3}$ and $0.2 \mathrm{M} \mathrm{NaHCO}_{3}$

Plant tissues were fixed with $3 \%$ paraformaldehyde, $0.25 \%$ glutaraldehyde in $0.1 \mathrm{M}$ sodium phosphate buffer $(\mathrm{pH} 7.4)$. Dehydration was performed in graded ethanol and xylol series, and tissues were embedded in paraplast (Brunswick). Sections ( $7 \mu \mathrm{m}$ thick) were attached to poly-L-lysine-coated slides. Sections were deparaffinized with xylol and rehydrated through a graded ethanol series. They were pretreated with $1 \mu \mathrm{g} / \mathrm{ml}$ proteinase $\mathrm{K}$ in $100 \mathrm{mM}$ Tris- $\mathrm{HCl}(\mathrm{pH} 7.5), 50 \mathrm{mM}$ EDTA at $37^{\circ} \mathrm{C}$ for $30 \mathrm{~min}$, and $0.25 \%$ acetic anhydride in $0.1 \mathrm{M}$ triethanolamine $(\mathrm{pH} 8.0)$ at room temperature for $10 \mathrm{~min}$. Subsequently they were dehydrated in a graded ethanol series and air dried. Sections were hybridized with RNA probes $\left(10^{6} \mathrm{cpm} / \mathrm{ml}\right)$ in $50 \%$ formamide, $0.3 \mathrm{M}$
$\mathrm{NaCl}, 10 \mathrm{mM}$ Tris- $\mathrm{HCl}$ (pH 7.5), $1 \mathrm{mM}$ EDTA, 10\% dextran sulphate, $1 \times$ Denhardt's solution, $500 \mu \mathrm{g} / \mathrm{ml}$ poly(A), $150 \mu \mathrm{g} / \mathrm{ml}$ yeast tRNA, and 70 $\mathrm{mM}$ DTT for $16 \mathrm{hr}$ at $42^{\circ} \mathrm{C}$. Washing was performed in $4 \times \mathrm{SSC}, 5 \mathrm{mM}$ DTT at room temperature. Next, sections were treated with $20 \mu \mathrm{g} / \mathrm{ml}$ RNAase A in $0.5 \mathrm{M} \mathrm{NaCl}, 5 \mathrm{mM}$ EDTA, $10 \mathrm{mM}$ Tris- $\mathrm{HCl}(\mathrm{pH} 7.5)$ at $37^{\circ} \mathrm{C}$ for $30 \mathrm{~min}$ and washed in the same buffer with $5 \mathrm{mM}$ DTT at $37^{\circ} \mathrm{C}$ for $30 \mathrm{~min}$. The final wash was performed twice with $2 \times$ SSC, $1 \mathrm{mM}$ DTT at room temperature. Sections were dehydrated in graded ethanol and air dried. Slides were coated with Kodak NTB2 nuclear emulsion diluted with an equal volume of $600 \mathrm{mM}$ ammonium acetate and exposed for $1-4$ weeks at $4^{\circ} \mathrm{C}$. They were developed in Kodak D19 developer for $3 \mathrm{~min}$ and fixed in Kodak fix. Sections were stained with $0.025 \%$ toluidine blue $O$ for $5 \mathrm{~min}$ and mounted with DPX

\section{Polymerase Chain Reactions}

One microgram of the synthetic oligomer 5'-CGTGCAAATGTGACTTCTTG-3', complementary to nucleotides 263-283 of the ENOD12 CDNA sequence, and $1 \mu \mathrm{g}$ of total root hair RNA were annealed by heating for $3 \mathrm{~min}$ at $85^{\circ} \mathrm{C}$ in a $10 \mu \mathrm{l}$ annealing buffer $(250 \mathrm{mM} \mathrm{KCl}, 1 \mathrm{mM}$ EDTA, and $10 \mathrm{mM}$ Tris- $\mathrm{HCl}[\mathrm{pH} 8.3]$, incubating for $30 \mathrm{~min}$ at $52^{\circ} \mathrm{C}$, and gradually cooling to $42^{\circ} \mathrm{C}$ for $30 \mathrm{~min}$. A $15 \mu$ cDNA buffer $(10 \mathrm{mM}$ $\mathrm{MgCl}_{2}, 8 \mathrm{mM}$ DTT, $0.4 \mathrm{mM}$ of all four dNTPs, and $25 \mathrm{mM}$ Tris- $\mathrm{HCl}[\mathrm{pH}$ 8.3]) and $5 U$ of AMV reverse transcriptase (Life Science) were added, and ENOD12-specific CDNA was synthesized at $42^{\circ} \mathrm{C}$ for $60 \mathrm{~min}$. Then, a $55 \mu \mathrm{l}$ Taq polymerase buffer $\left(30 \mathrm{mM}\left(\mathrm{NH}_{4}\right)_{2} \mathrm{SO}_{4}, 9 \mathrm{mM} \mathrm{MgCl}{ }_{2}, 10\right.$ $\mathrm{mM} \beta$-mercaptoethanol, and $100 \mathrm{mM}$ Tris- $\mathrm{HCl}$ [pH 8.8]), $20 \mu \mathrm{ll}$ of $5 \mathrm{mM}$ dNTPs, $10 \mu \mathrm{l}$ of DMSO, $1.25 \mu \mathrm{l}$ of $2 \mathrm{M} \mathrm{KCl}, 1 \mu \mathrm{g}$ of the synthetic oligomer 5'-CTTGTCCTCACTAGTGTT-3' (nucleotides 21-41 of the ENOD12 CDNA sequence), and $2 U$ of Taq polymerase (Cetus) were added. The mixture was heated for $3 \mathrm{~min}$ at $92^{\circ} \mathrm{C}$, annealed for $2 \mathrm{~min}$ at $52^{\circ} \mathrm{C}$, and 12-16 of the following amplification cycles were performed: $5 \mathrm{~min}$ at $70^{\circ} \mathrm{C}, 1 \mathrm{~min}$ at $92^{\circ} \mathrm{C}$, and $1 \mathrm{~min}$ at $52^{\circ} \mathrm{C}$. Amplified cDNA was ethanol precipitated, the pellet was dissolved in TE buffer, and nucleic acids were separated on a $2 \%$ agarose gel. Upon DNA transfer blotting, the amplified fragment was visualized by hybridization to a ${ }^{32} \mathrm{P}$-labeled ENOD12 insert.

As established by three initial experiments, the concentration differences between amplified ENOD12 cDNA from the different root hair RNA preparations reflected differences in the initial mRNA concentrations: First, differences in ENOD12 mRNA concentrations as revealed by the PCR method matched the differences revealed by RNA transfer blot analysis of $20 \mu \mathrm{g}$ of root hair RNA (compare Figures 6 and 1B, WT and nodA ${ }^{-}$lanes). Second, PCR experiments on a dilution series of total nodule RNA revealed that, with 12-16 amplification cycles, initial mRNA concentration differences were reflected in the differences of the amounts of amplified ENOD12 cDNA. Third, amplification rates in different total root hair RNA preparations were compared by taking samples after different numbers of cycles. It appeared that the ENOD12 cDNA concentration indeed increased at the same rate in different root hair RNA preparations.

\section{Primer Extension Analysis and RNA Sequencing}

The synthetic oligomer 5'-AGGTGATATTGAGCAAGTCC-3', complementary to nucleotides 70-90 of the pPsENOD12 sequence, was labeled using T4 polynucleotide kinase (Pharmacia); $1 \times 10^{6} \mathrm{cpm}$ of this primer was coprecipitated with $20 \mu \mathrm{g}$ of total RNA. Nucteic acids were resuspended in a $6.25 \mu$ annealing buffer $(50 \mathrm{mM}$ Tris- $\mathrm{HCl}[\mathrm{pH}$ 8.2), $60 \mathrm{mM} \mathrm{NaCl}, 10 \mathrm{mM}$ DTT), heated to $68^{\circ} \mathrm{C}$, and allowed to cool down to $35^{\circ} \mathrm{C}$. A $2.25 \mu$ RT buffer $(250 \mathrm{mM}$ Tris- $\mathrm{HCl}$ [pH 8.2], $30 \mathrm{mM}$ $\mathrm{MgCl}_{2}, 500 \mathrm{mM} \mathrm{NaCl}, 50 \mathrm{mM}$ DTT), $2.5 \mu l$ of dNTP mixture $(2 \mathrm{mM})$, and $0.5 \mu$ l of AMV reverse transcriplase (Life Science) $(25 \mathrm{U} / \mu \mathrm{l})$ were added, and primer extension was performed at $45^{\circ} \mathrm{C}$ for $20 \mathrm{~min}$. Subsequently, $1 \mu$ of RNAase A was added, and incubation was prolonged for $15 \mathrm{~min}$. The mixture was extracted once with phenol-chloroform (1:1) and ethanol precipitated using $2 \mu \mathrm{g} / \mathrm{ml}$ tRNA as a carrier. Upon resuspension in $1.5 \mu \mathrm{l}$ of $\mathrm{H}_{2} \mathrm{O}$, loading buffer was added; after denaturation, samples were analyzed on a $6 \%$ polyacrylamide- $8 \mathrm{M}$ urea sequencing gel.

For RNA sequencing $5 \times 10^{6} \mathrm{cpm}$ of primer was coprecipitated with $80 \mu \mathrm{g}$ of total RNA. The precipitate was resuspended in $12.5 \mu \mathrm{l}$ of annealing buffer and annealed as described above. Then, a $4.5 \mu \mathrm{l}$ RT buffer, $5 \mu$ l of dNTP mixture ( $2 \mathrm{mM}$ ), and $25 \mathrm{U}$ of AMV reverse transcriptase were added; $4 \mu \mathrm{l}$ of this solution was added to four separate 
tubes containing $1 \mu$ of one of the four dideoxy NTPs $(800 \mu \mathrm{M})$. Extension was performed for $20 \mathrm{~min}$ at $45^{\circ} \mathrm{C}$. Subsequently, $1 \mu$ of the dNTP mixture was added for a chase reaction for $15 \mathrm{~min}$ at $45^{\circ} \mathrm{C}$. Samples were extracted, precipitated, and subjected to gel analysis as described above.

\section{RNAase Mapping}

The region of pPsENOD12 from the Bgll site at position 246 up to the Ball site at position 448 containing 202 nucleotides from the $3^{\prime}$ end of the cDNA was cloned into pT7-6. Antisense RNA was transcribed from this plasmid, after linearization immediately behind the insert, using T7 RNA polymerase (New England Biolabs) and [ $\left.{ }^{32} \mathrm{P}\right]$ UTP (New England Nuclear Corp.) as labeled nucleotide. Unlabeled UTP $(50 \mu \mathrm{M})$ was added to ensure $95 \%-100 \%$ of full-size transcription. After synthesis the reaction was stopped with DNAase I (Boehringer) extracted once with phenol-chloroform (1:1) and once with chloroform, and unincorporated nucleotides were removed by spin-column chromatography (Maniatis et al 1982)

For RNAase mapping, $1 \times 10^{5} \mathrm{cpm}$ of probe was coprecipitated with $20 \mu \mathrm{g}$ of total RNA. Pellets were resuspended in a $30 \mu \mathrm{l}$ hybridization buffer, and following denaturation at $85^{\circ} \mathrm{C}$ for $5 \mathrm{~min}$, the mix was incubated for $16 \mathrm{hr}$ at $45^{\circ} \mathrm{C}$ (Melton et al., 1984). Digestion with 640 to $5760 \mathrm{U} / \mathrm{ml}$ RNAase T1 (Bethesda Research Laboratories) was performed at $45^{\circ} \mathrm{C}$ for $60 \mathrm{~min}$, RNAases were removed by an additional incubation for $15 \mathrm{~min}$ with proteinase $\mathrm{K}$ and $\mathrm{SDS}$ at $37^{\circ} \mathrm{C}$, all as described by Melton et al. (1984). The mixlure was extracted with phenolchloroform (1:1) and precipitated with carrier tRNA and ethanol. The pellet was resuspended in $\mathrm{H}_{2} \mathrm{O}$, loading buffer was added, and upon denaturation, samples were analyzed on $6 \%$ polyacrylamide-8M urea sequencing gels.

\section{Acknowledgments}

We wish to thank Dr. G. Coruzzi and Dr. S. Tigney for providing us with a pea nodule cDNA library; Dr. E. Pees for making available the $R$ leguminosarum bv. viciae A10 strain; Dr. T. V. Bhuvaneswari for critical reading of the manuscript; Dr. C. Diaz and Dr. B. Bakhuizen for useful suggestions; Dr. A. van Lammeren for support; P. Madern, P. van Druten, S. Massalt, and Dr. S. de Vries for artwork; and P. de Kam for growing plants. B. S. was supported by the Dutch Organization for Scientific Research (NWO). B. H. was supported by a European Molecular Biology Organization fellowship.

The costs of publication of this article were defrayed in part by the payment of page charges. This article must therefore be hereby marked "advertisement" in accordance with 18 U.S.C. section 1734 solely to indicate this fact.

Received July 19, 1989; revised October 12, 1989.

\section{References}

Averyhart-Fullard, V., Datta, K., and Marcus, A. (1988). A hydroxyproline rich protein in the soybean cell wall. Proc. Natl. Acad. Sci. USA 85, 1082-1085

Bakhuizen, R., van Spronsen, P. C., Diaz, C. L., and Kijne, J. W. (1988) The plant cytoskeleton in the Rhizobium-legume symbiosis, Ph.D. the sis, Leiden University, The Netherlands, pp. 57-81, 83-107.

Bauer, W. D. (1981). Infection of legumes by rhizobia. Annu. Rev. Plant Physiol. 32, 407-449.

Bennett, M. J., Lightfoot, D. A., and Cullimore, J. V. (1989). cDNA sequence and differential expression of the gene encoding the glutamine synthetase polypeptide of Phaseolus vulgaris L. Plant Mol. Biol. 12, 553-565.

Bergmann, H., Preddie, E., and Verma, D. P. S. (1983). Nodulin-35: a subunit of specific uricase (uricase II) induced and localized in the uninfected cells of soybean nodules. EMBO J. 2, 2333-2339.

Bisseling, T., Van den Bos, R. C., and Van Kammen, A. (1978). The effect of ammonium nitrate on the synthesis of nitrogenase and the concentration of leghemoglobin in pea root nodules induced by Rhizobium leguminosarum. Biochim. Biophys. Acta 539, 1-11.

Bogusz, D., Appleby, C. A., Landsmann, J., Dennis, E. S., Trinick, M., and Peacock, W. J. (1988). Functioning haemolglobin in non-nodu lating plants. Nature $331,178-180$.

Brisson, N., and Verma, D. P. S. (1982). Soybean leghemoglobin gene family: normal, pseudo, and truncated genes. Proc. Natl. Acad. Sci. USA 79, 4055-4059.

Callaham, D. A., and Torrey, J. G. (1981). The structural basis for infection of root hairs of Trifolium repens by Rhizobium. Can. J. Bot. 59, 1947-1964.

Chen, J., and Varner, J. E. (1985). Isolation and characterization of cDNA clones for carrot extensin and a proline-rich 33-kDa protein. Proc. Natl. Acad. Sci. USA 82, 4399-4403.

Corbin, D. R., Sauer, N., and Lamb, C. J. (1987). Differential regulation of a hydroxyproline-rich glycoprotein gene family in wounded and infected plants. Mol. Cell. Biol. 7, 4337-4344.

Cox, K. H., DeLeon, D. V., Angerer, L. M., and Angerer, R. C. (1984), Detection of mRNAs in sea urchin embryos by in situ hybridization using asymmetric RNA probes. Dev. Biol. 101, 485-502.

Darvill, A. G., and Albersheim, P. (1984). Phytoalexins and their elicitors - a defense against microbial infection in plants. Annu. Rev. Physiol. 35, 243-275.

De Vries, S. C., Springer, J., and Wessels, J. H. G. (1982). Diversity of abundant mRNA sequences and patterns of protein synthesis in etiolated and greened pea seedlings. Planta 156, 129-135.

Dickstein, R., Bisseling, T., Reinhold, V. N., and Ausubel, F. M. (1988) Expression of nodule-specific genes in alfalfa root nodules blocked at an early stage of development. Genes Dev. 2, 677-687.

Djordjevic, M. A., Gabriel, D. W., and Rolfe, B. G. (1987). Rhizobiumthe refined parasite of legumes. Annu. Rev. Phytopathol. 25, 145-168. Faucher, C., Camut, S., Denarie, J., and Truchet, G. (1989). The nodH and nodQ host range genes of Rhizobium meliloti behave as avirulence genes in Rhizobium leguminosarum bv. viciae and determine changes in the production of plant-specific extracellular signals. Mol. Plant-Microbe Interact. 2, 291-300.

Fortin, M. G., Zelechowska, M., and Verma, D. P. S. (1985). Specific targeting of membrane nodulins to the bacteroid-enclosing compartment in soybean nodules. EMBO J. 4, 3041-3046.

Fortin, M. G., Morrison, N. A., and Verma, D. P. S. (1987). Nodulin-26, a peribacteroid membrane nodulin is expressed independently of the development of the peribacteroid compartment. Nucl. Acids Res. 15 813-824.

Franssen, H. J., Nap, J. P., Gloudemans, T., Stiekema, W., Van Dam, H., Govers, F., Louwerse, J., Van Kammen, A., and Bisseling, T. (1987) Characterization of cDNA for nodulin-75 of soybean: a gene product involved in early stages of root nodule development. Proc. Natl. Acad. Sci. USA 84, 4495-4499.

Franssen, H. J., Scheres, B., Van De Wiel, C., and Bisseling, T. (1988) Characterization of soybean (hydroxy)proline-rich early nodulins. In Molecular Genetics of Plant-Microbe Interactions, R. Palacios and D. P. Verma, eds. (St. Paul: APS Press), pp. 321-326.

Gloudemans, T., Bhuvaneswari, T. V., Moerman, M., Van Brussel, T. Van Kammen, A., and Bisseling, T. (1989). Involvement of Rhizobium leguminosarum nodulation genes in gene expression in pea root hairs. Plant Mol. Biol. 12, 157-167.

Govers, F., Gloudemans, T., Moerman, M., Van Kammen, A., and Bisseling, T. (1986). Rhizobium nod genes are involved in inducing an early nodulin gene. Nature 323, 564-566.

Govers, F., Nap, J. P., Van Kammen, A., and Bisseling, T. (1987). Nodulins in the developing root nodule. Plant Physiol. Biochem. 25, 309322.

Horvath, B., Kondorosi, E., John, M., Schmidt, J., Török, I., Györgypal Z., Barabas, I., Wieneke, U., Schell, J., and Kondorosi, A. (1986). Organization, structure and symbiotic function of Rhizobium meliloti nodulation genes determining host specificity for alfalfa. Cell 46, 335-343. Jacobs, F. A., Zhang, M., Fortin, M. G., and Verma, D. P. S. (1987). Several nodulins of soybean share structural domains but differ in their subcellular locations. Nucl. Acids Res. 15, 1271-1280.

Korneluk, R. G., Quan, F., and Gravel, R. A. (1985). Rapid and reliable dideoxy sequencing of double-stranded DNA. Gene 40, 317-323. 
Libbenga, K. R., and Bogers, R. J. (1974). Root nodule morphogenesis. In The Biology of Nitrogen Fixation, A. Quispel, ed. (Amsterdam: North Holland Publishing Company), pp. 430-472.

Libbenga, K. R., Van Iren, F., Bogers, R. J., Schraag-Lamers, M. F. (1973). The role of hormones and gradients in the initiation of cortex proliferation and nodule formation in Pisum sativum L. Planta 114 29-39.

Long, S. R. (1989). Rhizobium-legume nodulation: life together in the underground. Cell 56, 203-214.

Maniatis, T., Fritsch, E. F, and Sambrook, J. (1982). Molecular Cloning: A Laboratory Manual. (Cold Spring Harbor, New York: Cold Spring Harbor Laboratory)

Melton, D. A., Krieg, P. A., Rebabliati, M. R., Maniatis, T., Zinn, K., and Green, M. R. (1984). Efficient 'in vitro' synthesis of biologically active RNA and RNA hybridization probes from plasmids containing a bacteriophage SP6 promoter. Nucl. Acids Res. 12, 7035-7056.

Mullis, K. B., and Faloona, F. A. (1987). Specific synthesis of DNA in vitro via a polymerase-catalyzed chain reaction. Meth. Enzymol. 155 $335-350$

Newcomb, W. (1976). A correlated light and electron microscopic study of symbiotic growth and differentiation in Pisum sativum root nodules. Can. J. Bot. 54, 2163-2186.

Newcomb, W. (1980). Control of morphogenesis and differentiation of pea root nodules. In Nitrogen Fixation, Vol. II, W. E. Newton and W. H. Orme-Johnson, eds. (Baltimore: University Park Press), pp. 87-102.

Rigaud, G., Grange, T., and Pictet, R. (1987). The use of $\mathrm{NaOH}$ as transfer solution onto nylon membrane decreases the hybridization efficiency. Nucl. Acids Res. 15, 857

Rogers, S. O., and Bendich, A. J. (1988). Extraction of DNA from plant tissues. In Plant Molecular Biology Manual, S. B. Gelvin and R. A. Schilperoort, eds. (Dordrecht: Kluwer Academic Publishers), A6, pp. 1-10.

Saiki, S., Scharf, F., Faloona, K., Mullis, G., Horn, G., Erlich, H., and Arnheim, N. (1985). Enzymatic amplification of $\beta$-globin genomic sequences and restriction site analysis for diagnosis of sickle cell anemia. Science 230, 1350-1354.

Sandal, N. N., Bojsen, K., and Marcker, K. A. (1987). A small family of nodule specific genes from soybean. Nucl. Acids Res. 15, 1507-1519. Schmidt, J., Wingender, R., John, M., Wieneke, U., and Schell, J. (1988). Rhizobium meliloti nodA and nodB genes are involved in generating compounds that stimulate mitosis of plant cells. Proc. Natl. Acad. Sci. USA 85, 8578-8582.

Showalter, A. M., Bell, J. N., Cramer, C. L., Bailey, J. A., Varner, J. E., and Lamb, C. J. (1985). Accumulation of hydroxyproline-rich glycoprotein mRNAs in response to fungal elicitor and infection. Proc. Natl. Acad. Sci. USA 82, 6551-6555.

Spaink, H. P., Okker, R. J. H., Wijfelman, C. A., Pees, E., and Lugtenberg. B. J. J. (1987). Promoters in the nodulation region of the Rhizobium leguminosarum sym plasmid PRLiJI. Plant Mol. Biol. 9, 29-37. Tigney, S. V., Walker, E. L., and Coruzzi, G. M. (1987). Glutamine syntetase genes of pea encode distinct polypeptides which are differentially expressed in leaves, roots and nodules. EMBO J. 6, 1-9.

Turgeon, B. G., and Bauer, W. D. (1985). Ultrastructure of infectionthread development during the infection of soybean by Rhizobium japonicum. Planta 163, 328-349.

Van Brussel, A. A. N., Pees, E., Spaink, H. P., Tak, T., Wijffelman, C. A., Okker, R. J. H., Truchet, G., and Lugtenberg, B. J. J. (1988). Correlation between Rhizobium leguminosarum nod genes and nodulation phenotypes on vicia. In Nitrogen Fixation, Hundred Years After, H. Bothe, F. J. de Bruijn, and W. E. Newton, eds. (Stuttgart-New York: Gustav Fisher), p. 483.

Vance, C. P. (1983). Rhizobium infection and nodulation: a beneficial plant disease? Annu. Rev. Microbiol. 37, 399-424.

Van De Wiel, C., Scheres, B., Franssen, H. J., van Lierop, M. J., van Lammeren, A., Van Kammen, A., and Bisseling. T. (1990). The early nodulin transcript ENOD2 is located in the nodule parenchyma (inner corlex) of pea and soybean root nodules. EMBO J., in press.

Van Kammen, A. (1984). Suggested nomenclature for plant genes involved in nodulation and symbiosis. Plant Mol. Biol. Rep. 2, 43-45.
Von Heijne, G. (1983). Patterns of amino acids near signal-sequence cleavage sites. Eur. J. Biochem. 133, 17-21.

Wijffelman, C. A., Pees, E., Van Brussel, A. A. N., Okker, R. J. H., and Lugtenberg, B. J. J. (1985). Genetic and functional analysis of the nodulation region of Rhizobium leguminosarum sym plasmid pRL1.JI Arch. Microbiol. 143, 225-232.

Zaat, S. A. J., Van Brussel, A. A. N., Tak, T., Pees, E., and Lugtenberg, B. J. J. (1987). Flavonoids induce Rhizobium leguminosarum to produce nodDABC gene-related factors that cause thick, short roots and root hair responses on common vetch. J. Bacteriol. 169, 3388-3391. 